Aifuwa, H.O. (2020). Sustainability reporting and firm performance in developing climes: A review of literature. Copernican Journal of Finance \& Accounting, 9(1), 9-29. http://dx.doi. org/10.12775/CJFA.2020.001

Hope Osayantin Aifuwa*

University of Benin

\title{
SUSTAINABILITY REPORTING AND FIRM PERFORMANCE IN DEVELOPING CLIMES: A REVIEW OF LITERATURE
}

Keywords: GRI, economic reporting, social reporting, environmental reporting, developing climes.

\section{J E L Classification: M41, K32.}

\begin{abstract}
The study basically examined the impact of sustainability reporting on firm performance in developing climes. A systematic content analysis approach was adopted in the study and it formed the basis for the researcher's conclusion and recommendations. The findings of reviewed extant literature showed that there were inconclusive findings on the impact of sustainability reporting on firm performance. However, a large number of works submitted a positive relationship between sustainability reporting and firms' performance. Secondly, financial performance measures often used by researchers include the profitability measures (ROA and ROE) and market-base measure (EPS and DPS), and the fourth version of the Global Reporting Initiative (GRI) framework in calculating sustainability disclosure index via content analysis. Thirdly, we also found that sustainability disclosure level was low in developing climes compared to other developed climes. We observed some methodological flaws in extant literature on the sector investigated and sample size employed. This study, therefore, recommended that further studies should be carried out on the impact of sustainability reporting on firms' performance based on the suggested methodological improvement.
\end{abstract}

Date of submission: March 26, 2020; date of acceptance: May 17, 2020.

* Contact information: aifuwahopeosayantin@gmail.com, Department of Accounting, Faculty of Management Sciences, University of Benin, Benin City, Edo State, Nigeria, phone: +2348113232082; ORCID ID: https://orcid.org/0000-0001-8908-6637. 


\section{IIINTRODUCTION}

No business can exist without interaction from its environment. This interaction with the environment is a vital strategy for survival and thus enables it to be self-sufficient and reliant and above all, be sustainable. In order to achieve maximum sustainability in business operations, an organization must minimize such negative impacts as its emissions, waste, social issue, and unfair treatment of business employees to the barest minimum. When this is achieved, then a company could be said to have performed well (Joseph, 2016).

Firms' performance, in the present dispensation, simply means how a firm effectively and efficiently harnesses its limited resources (land, labour and capital) at its disposal to create value. To create value simply means achieving sufficient profit and at the same time satisfying the need of diversified groups of stakeholders (Burhan \& Ramanti, 2012). A firm's ability to manage its financial and non-financial activities is very crucial to its survival (Taouab \& Issor, 2019). When this is achieved at a significant level in a firm, it is said to be sustainable.

The concept of sustainable development or sustainability gained prominence following the 1987 Brundtland Report on bridging the gap between environmental and human development concerns (Bebbington \& Larrinaga, 2014; Bebbington \& Unerman, 2017). The concept further gained more popularity following the United Nation's Transformation Agenda which should be achieved before the year 2030. The United Nations (UN) adopted the Organization for Economic and Community Development's (OECD) Millennium Development Goals (MDGs) developed in 1966 and modified it into seventeen sustainable development goals (SDGs) (Bebbington \& Unerman, 2017). The main objective of the SDGs is to improve social, ecological and economic outcomes by governments and businesses across the globe (Kim, 2016; UN, 2016). Thus, businesses can promote the UN's sustainable development agenda or goals through sustainability reporting.

Sustainability reporting is the process whereby companies disclose their economic, environmental and social impacts on society and environment as a result of their daily business activities (Global Reporting Initiative [GRI], 2019). Business firms are not socially and environmentally responsible because their activities cause environmental degradation, climate change, pollution and even poverty in the environments and communities they operate in. 
Scientists have also noted that the ecosystem has changed drastically as a result of firms' activities (Kusuma \& Koesrindartoto, 2014). Firms' irresponsible attitude is evident in its' financial statements. That at the end of every financial year, firms report huge profits, and then claim to perform at the detriment of the environment and community where they operate in (Johari \& Komathy, 2019). This irresponsible attitude exhibited by business firms can reduce their long-term value.

Along this line, researchers have empirically investigated the impact of sustainability reporting on firms' performance, and have found an inconclusive result. The inconclusive findings could be as a result of methodology flaws such as the failure to incorporate non-financial dimensions in determining firms' performance and also that no reliability and validity test was conducted on the index of sustainability employed (either dichotomous or polychotomous index) (See, Adams, Thornton \& Sepehri, 2012; Aggarwal, 2013; Asuquo, Dada \& Onyeogaziri, 2018; Beredugo \& Mefor, 2016; Burhan \& Rahmanti, 2012; Dhaliwal, Li, Tsang \& Yang, 2011; Isa, 2014; Nwobu, 2015; Onyekwelu \& Ugwuanyi, 2014; Venanzi, 2012). This identified gap therefore, provided the motivation for the study.

The objective of this study was to review the literature on the impact of sustainability reporting on firms' performance as there seemed to be inconclusive findings in literature on the nexus between sustainability reporting and firms' performance incorporating. Against the above backdrop, we raised the research question: What is the impact of sustainability reporting on firm performance in developing climes?

\section{THE RESEARCH METHODOLOGY AND THE COURSE OF THE RESEARCH PROCESS}

A systematic content analysis approach was used to shortlist relevant publications from literature. This review focuses on major peer-reviewed journals indexed in quality and impact rankings on developing countries between the periods of 2014-2019 to know current state of research during their respective times of publication. In selecting articles that research the impact of sustainability practices on corporate firm performance, several keywords were used: corporate sustainability, social sustainability, environmental sustainability, firm performance, financial performance, and non-financial performance. 
Only peer-reviewed articles available with their full text in the English language were included in the research. Rounds of article elimination took place to shortlist articles related to the subject of the impact of sustainability practices on corporate financial performance. Starting with preprints resulted in further elimination of articles and the addition of new ones from various databases:

- Google Scholar

- Researchgate

- SSRN

- Semantic Scholar

This systematic approach shortlisted a total of fifty-four (54) articles publications for examination. Most of the excluded literature focused corporate social responsibility disclosure and social performance.

\section{CONCEPTUAL FRAMEWORK}

\section{Firm performance}

The concept of firms' performance is generic. For a business firm, it is mostly about making profit. For a government organization or non-governmental organization (NGO), it is good governance and rendering of quality welfare services to the citizens or people. Apart from being generic, the concept of firms' performance is also dynamic. Its definition changes from decade to decade as a result of the focus of firms in these periods, thus, this make it hard for the concept to be clearly defined (Taouab \& Issor, 2019).

In the 50's, firms' performance was considered as the equivalent of organizational efficiency (Taouab \& Issor, 2019). It was seen as the degree to which an organization achieved its goals with minimum efforts from its workers and also with limited resources (Georgopoulos \& Tannenbaum, 1957). In the 60's and 70 's, firms' performance was seen as the ability of an organization to exploit its environment using limited resources (Katz \& Kahn, 1978; Lupton, 1977; Yuchtman \& Seashore, 1967). In the 80's, firms' performance was defined as the ability of an organization to create value for its clients (Cherrington, 1989; Robbins, 1987). It was also seen as profoundly dependent on employees' performance quality in the 90's (Adam, 1994; Harrison \& Freeman, 1999). 
In the first decade of the twenty-first century, the concept of firms' performance was defined as the capability and ability of an organization to efficiently utilize its available resources to achieve its goals, and at the same time, adds value to its shareholders (Lebans \& Euske, 2006). A significant change in the definition of the concept emerged in the second decade of the twenty-first century. Where it was seen as the ability of an organization to achieve its set objectives and goal from limited resources at its disposal and, in the process, also satisfy the needs of its stakeholders (Isaiah, Selvam, Vinayagamoorthi, Kasilingam \& Mariappan, 2015; Selvam, 2016; Selvam, Gayathri, Vansanth, Lingaraja \& Marxiaoli, 2016).

Flowing from the last definition, the make-up of firms' performance financial and non-financial performances (or strategic or operational performance). Theoretically, the definition of firms' performance is hinged on the economic view of profit maximization of the organization and the stakeholders approach of satisfying the need of a group or individuals who are affected by the activities of the same organization. Financial performance is a subjective measure of how a firm effectively and efficiently utilises its assets to generate resources (Nnamani, Onyekwelu \& Ugwu, 2017). The financial performance of an organization is classified in subsets of profitability performance (return on assets (ROA), return on equity (ROE), return on investment (ROI), economic value added (EVA), net income/revenue and earnings before interest, tax, depreciation and amortization margin (EBTIDA), market value performance (earnings per share (EPS), change in stock price, dividend yield, stock price volatility, market value added (MVA) and Tobin Q) while growth dimension of performance consists of market share growth, asset growth, net revenue growth, net income growth and number of employees growth (Santos \& Brito, 2012).

Many researchers have often focused on the profitability measures of financial performance (e.g. ROA and ROE) as a proxy for firms' performance (Alshehhi, Nobanee \& Khare, 2018), while totally ignoring the non-financial performance measures. Non-financial performance measures include customer satisfaction (mix of products and services, number of complaints, repurchase rate, new customer retention, and general customer satisfaction) and environmental performance (number of projects to improve the environment, level of energy intensity, use of recyclable materials, volume of energy consumption, number of environmental lawsuit, recycling level and reuse of residual).

Social performance consists of the employment of minorities, a number of social and cultural projects, number of lawsuits filed by employees and cus- 
tomers, and regulatory agencies. Similarly, an employee's performance consists of turnover, investment in employee development \& training, wages \& reward policy, career plans, organization climate, and general employee satisfaction. Corporate governance performance is made up of board size, board independence, foreign directors and insider ownership (Santos \& Brito, 2012; Selvam et al., 2016).

\section{Sustainability reporting}

The phrase, Sustainability Reporting, is a blend of two concepts: Sustainability and Reporting. Whilst the former is meeting the needs of the present generation without compromising the ability of future generations to meet their own needs (Brundtland, 1987), the latter simply means disclosing an organization's information fully or partially to stakeholders who need it for different purposes. Therefore, sustainability reporting [SR] (or disclosure or performance) is the integration of reporting and accounting for economic, environmental and social into corporate reporting (Elkington, 2004). The Global Reporting Initiative [GRI] (2019) defines sustainability reports as those issued by firms about their economic, environmental and social impacts caused by their daily operation activities. Hahn, Preuss, Pinkse and Figge (2014) described SR as a set of a company's activities that demonstrate the inclusion of social and environmental concerns in business operations and interactions with stakeholders. This report is therefore, aimed at achieving sustainable development goals (Gunarsih \& Ismawati, 2018).

The concept of sustainable reporting evolved in the 1980's when the first environmental reports appeared. Johari and Komathy (2019) and Joseph (2016) were of the opinion that SR evolved through the stages of employee reporting to social reporting to environmental reporting to triple bottom line reporting and finally, to SR. The reasons for SR are many, but the most striking ones are to measure and improve firms' performance upcoming financial results and furnish stakeholders with the information of the organization's going-concern status (Johari \&Komathy, 2019). SR has had a significant acceptance rate globally, mostly from developed and a few developing countries like South Africa (Ofoegbu, Odoemelam \& Okafor, 2018; Aifuwa, Saidu, Enehizena \& Osazevbaru, 2019). However, the same cannot be said of Least Developed Countries (LDC) like Myanmar, Bangladesh, Cambodia, Ethiopia (Wokeck, 2019; Aifuwa 
et al., 2019). Johari and Komathy (2019) observed that Europe had the highest sustainability disclosure rate of about forty-nine percent (49\%) followed by Asia with fifteen percent (15\%), North America fourteen percent (14\%), Latin America twelve percent (12\%), Oceania six percent (6\%) and Africa with the least rate of only four percent (4\%). It is also noteworthy that ninety percent $(90 \%)$ of the world's largest companies report their sustainability practices, with most of them using the GRI framework (Klynveld Peat Marwick Goerdeler [KPMG], 2017).

The GRI framework is perhaps one of the most popular frameworks for reporting economic, environmental and social issues of an organization (Laskar, 2018). Other developed frameworks include Business in The Community (BiTC), Dow Jones Sustainability Index (DJSI), Business Ethics 100, AccountAbility (AA) rating (Hopkins, 2005), International Integrated Reporting Council (IIRC), Carbon Disclosure Project, Sustainability Accounting Standard Board (SASB) and Global Framework for Climate Risk Disclosures (GFCRD) (Siew, Balatbat \& Carmichael, 2013; Emeka-Nwokeji \& Osisioma, 2019).

\section{Global Reporting Initiative (GRI) Framework}

GRI is the most widely recognised global framework for SR. It was founded in Boston in 1997 and established as an international non-for-profit organization in Amsterdam in 2002. The mission of the organization was to improve organizational contributions towards sustainable development by creating credible SR standard and practices (GRI, 2019) and encouraging uniformity for all companies and organizations in disclosing economic, environmental and social issues regardless of size, sector and region (Willis, Campagnoni \& Gee, 2015).

GRI issued its first set of standards known as G1 in 2000. Two years later, they issued the second set of standards - G2. In 2006, the GRI issued its third set of standards - G3. The G3 main elements comprised reporting guidelines, sector supplements and indicator protocols as discussed in detail (G3, 2006). Notably, clarifications were made on what to report and how to report economic, environmental and social issues (Johari \& Komathy, 2019). Five years later, the G3 was recalled and substituted with a new version of the standard called the G3.1.

A couple of years later, the G4 version was introduced and the previous standards were recalled. The G4 concentrates more on and emphasizes materi- 
ality and sustainability context. The G4 has two sections - the general standard disclosures (GSD) and specific standard disclosures (SSD) (Owolabi, Taleatu, Adetula \& Uwuigbe, 2016; Willis et al., 2015). The GSD has seven subsections that include organizational profile, strategy and analysis, identified material aspects and boundaries, stakeholder engagement, report profile, governance and ethics, and integrity. The SSD has three subsections which include the disclosure on management approach, indicators (economic, environmental and social) and specific disclosure sectors (Willis et al., 2015).

Figure 1. Evolution of GRI and SR Standards Issued

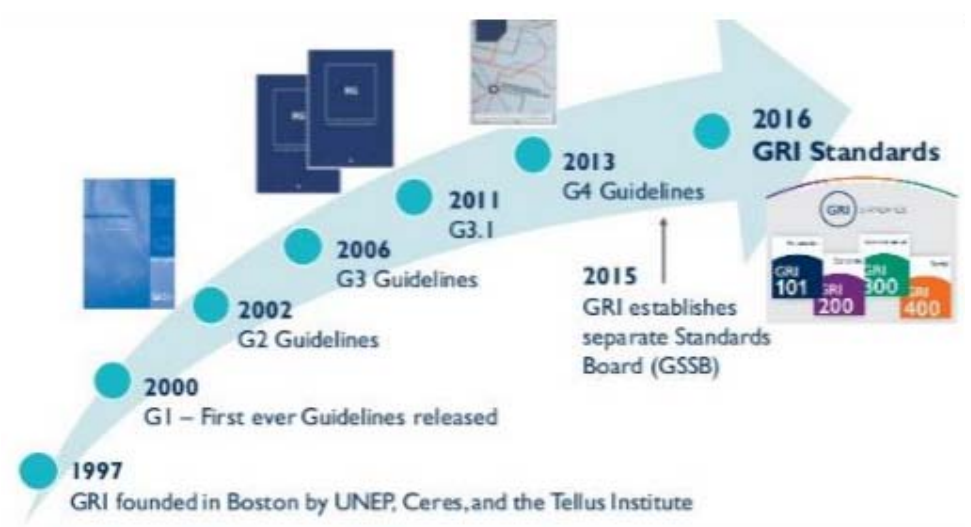

S o u r c e : Johari and Komathy (2019).

In 2016, the GRI G4 guidelines changed to GRI Sustainability Reporting Standard. That was the latest standard of sustainability issued by the GRI and it was built upon the G4 guidelines, but it was slightly different in terms of clearer requirements, contents, flexibility and transparency (GRI, 2019; Willis et al., 2015). Again, these latest standards are divided into two sections - the Universal standards (US) and the topic specific standards (TSS) (GRI, 2019). The US has three subsections: the foundation (GRI 101) which gives basic guidelines for any company that wants to report sustainability issues; the General disclosure (GRI 102) which gives a brief description of the company; and the management approach (GRI 103) which sets out the reporting requirements for organizations (Willis et al., 2015). The topic specific standards (TSS) also have three 
subsections. They include the economic dimensions also known as GRI 200, environmental dimensions (GRI 300) and social dimensions (GRI 400). Each of these dimensions also has subsections.

Figure 2. Latest Version of GRI standards on SR

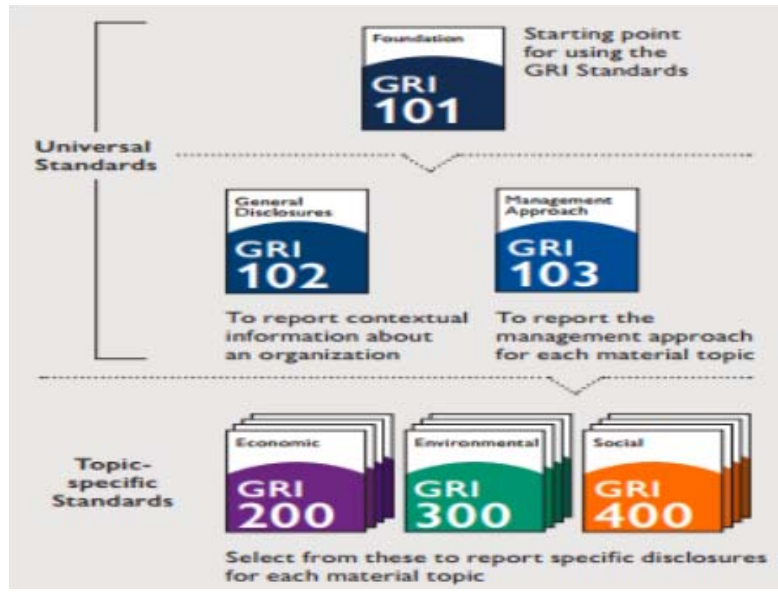

S o u r c e : Johari and Komathy (2019).

\section{Sustainability Reporting in Nigeria}

In Nigeria, sustainability reporting is not a listing requirement for firms from both the financial and non-financial sectors. This therefore, leads to the seemingly low compliance level and disclosure rate. SR is still voluntary among firms in Nigeria, but it is mostly practised by foreign firms having business outfits in Nigeria (Asaolu, Agboola, Ayoola \& Salawu, 2011; Emeka-Nwokoji \& Osisioma, 2019). Asaolu et al. (2011) observed that indigenous firms' attempts to disclose sustainability issues tended to use different frameworks either developed by them or adapted from already existing frameworks. The action therefore, tried to simply truncate the comparability principles for defining the quality of that report (GRI, 2015; Nwobu, 2015). No wonder, KPMG's (2011) survey on sustainability compliance revealed that Nigeria companies were still far behind in disclosing sustainability issues. 
Evidence from scholars substantiated the fact. Isa's (2014) study on sustainable reporting among food and beverage firms in Nigeria found that firms exhibited some level of sustainability reporting although it was not significant because it only comprised approximately two percent of the total disclosures of the annual reports. Owolabi et al. (2016) in assessing the sustainability reporting in Industrial Goods Sector using Lafarge Africa PLC as a case study, discovered that aggregate disclosure rate on sustainability issues was $30 \%$ which was quite low. Also, Haladu and Salim (2017) found that the average environmental and social disclosure rate by firms in Nigeria was $19.13 \%$. In the banking sector, sustainability disclosure rate followed the same dismal feat of about 34.31\% (Uwuigbe, Obarakpo, Uwuigbe, Ozordi, Asiriuwa, Eyitomi \& Taiwo, 2018), while in the oil and gas sector, it recorded a low rate also (Asaolu et al., 2011).

Also, most companies in Nigeria tend to disclose only qualitative issues on sustainability, and thus fail to inform the stakeholders of the quantitative or monetary implications of their activities on the environment (Kwaghfa, 2015). This tends to undermine the materiality of sustainability reports' content. The sustainability reports of firms in Nigeria tend to lack balance as they only report their positive environmental and social contributions to the environment where they operate thereby totally ignoring their negative impact. This truncates the balance principles for defining SR quality (GRI, 2015). Another observation of SR in Nigeria is that firms tend to choose what to disclose in the GRI framework. This has led to reports being skewed towardsa particular direction of the GRI framework. For example, the sustainability reports for firms in the financial sector tend be to skewed towards the social dimensions of SR only (Nwobu, 2015; Oyekwelu \& Ekwe, 2014; Oyewo \& Badejor, 2014), while the non-financial sector firms tend to report more on environmental issues (Nnamani et al., 2017; Owolabi et al., 2016). This therefore, leads to nonuniformity in the report on economic, environmental and social issues (Ayoola \& Olasanmi, 2013).

\section{Issues on sustainability reporting}

The emergence of sustainability reporting in recent times has sparked arguments as to whether it affects firms' performance. This argument sprang up as a result of some issues which surrounded sustainability reporting itself. Mu- 
ñoz, Zhao and Yang (2017) noted some areas where SR had issues which needed to be addressed swiftly and clearly to enable a wide acceptance rate and also high compliance. The areas included the definition of the concept, measurement and disclosure, motivation, enforcement and compliance, standardization, and the comparability \& reliability of the report.

The best definition of sustainability is the one given by GRI (Johari \& Komathi, 2019) and is far much better than what scholars have termed it to be. The definition encompasses three dimensions such as economic, environment and social impacts of a firm. Prior to this time, it had been defined as either corporate social responsibility reporting (Bayoud, Kavanagh \& Slaughter, 2012; Carroll, 1999; Venazi, 2012; Sadia, Tariq \& Saba, 2015; Statman \& Glushkov, 2019) environmental accounting or environmental reporting (Kathyayini, Tilt \& Lester, 2012; Saha \& Akter, 2013) or corporate social environmental reporting (Balabanis, Philips \& Lyall, 1998; Bowrin, 2013; Ismail \& Ibrahim, 2010). These scholars viewed sustainability reporting as the mix of either one or two dimensions and totally ignored its economic aspects.

Besides the issue of inconsistent definition of the concept of sustainability is the concept of measurement. Environmental issues like environmental degradation, water pollution and change in ecological structure cannot easily be and quantitatively measured as Jones (2014) pointed out. These issues are caused by the activities of an organization. Although scholars Sciences have come up with indices to measure some of these environmental issues like the Biological Integrity Index and the Watershed Index (Miller, Wardrop, Mahoney \& Brooks, 2006), the indices have however, been criticised for lacking expert accuracy in measuring the impact of organizations' activities on an environment. Similarly, the social dimensions have measurement issues. Humans (employees), are often regarded as assets in an organization, yet their value cannot be accurately ascertained. In a nutshell, the environmental and social dimensions of sustainability cannot be accurately measured in quantitative or monetary terms.

Another issue of sustainability reporting is the motive behind it. Most International companies do not see the need to report environmental and social issues if not for the pressure put on them by stakeholders (Hashmi, Damanhouri \& Rana, 2015). The case of domestic companies is far worse as they do not see the need to disclose sustainability issues regardless of the pressure from stakeholders (Muñoz, Zhao \& Yang, 2017). There seems to be no motivation for reporting mostly environmental and social issues. Contrary to this view, Al-Ga- 
marh and Al-Dharnari (2016) asserted that large companies were highly motivated to report sustainability issues because they wanted to acquire more market shares than small firms. Shamil, Shaikh, Ho and Krishnan (2014) opined that newly listed firms were more likely to produce reports on environmental and social issues than older firms because newly listed firms wanted to stay competitive in the market. In another view, Gulzar, Cherian, Sial, Badulescu, Thu, Badulescu and Khuong (2018) suggested that the main reason why firms reported environmental and social issues was principally to reduce their tax liability and subsequently avoid taxes.

The enforcement of SR is another challenge. The nature of the report is very voluntary. It thus, makes it hard to sanction erring firms on environmental and social issues. The Nigerian Stock Exchange (NSE) has bought into the ideal of SR by adopting the GRI framework however, the report is not made a listing requirement for firms (Asaolu et al., 2011). Even in the Corporate Governance Code of Nigeria (2018), sustainability reporting section seems scanty as compared to other sections of the Code. The lack of strict enforcement makes the compliance rate of this report very low.

The standards on SR across the globe are many. They are Business in The Community (BiTC), Dow Jones Sustainability Index (DJSI), Business Ethics 100, AccountAbility (AA) rating (Hopkins, 2005), International Integrated Reporting Council (IIRC), Carbon Disclosure Project, Sustainability Accounting Standard Board (SASB) and Global Framework for Climate Risk Disclosures (GFCRD) (Emeka-Nwokeji \& Osisioma, 2019). The issue of diverse standards on SR has slowed the reliability and comparability of sustainability reports.

In some empirical studies, researchers have come up with four views on the impact of SR on firms' performance. These views in literature are also called strands. The first strand in literature affirms that SR positively affects firms' performance (Amacha \& Dastane, 2017; Beredugo \& Mefor, 2016; Burhan \& Rahmanti, 2012; Diantimala, 2018; Ekweme, Egbunike \& Onyali, 2016; Kusuma \& Koesrindartoto, 2014; Nwobu, 2015; Onyekwelu \& Ugwuanyi, 2014). The second strand believes that additional costs will be incurred by firms in disclosing sustainability issues, and thus they do have a negative impact on firms' performance (Ching, Gerab \& Toste, 2017; Dhaliwal, Li, Tsang \& Yang, 2011; Isa, 2014; Utami, 2015). The third strand in literature states that there is no significant relationship between sustainability reporting and firms' performance (Adams et al., 2012; Asuquo et al., 2018; Ayoola \& Olasanmi, 2013; 
Venanzi, 2012). The fourth strand in literature states that SR partially affects firms' performance (mixed findings) (Aggarwal, 2013).

Nevertheless, majority of these researchers support the first trend in literature (Alshehhi et al., 2018). However, there still exists a condition of inconclusive findings on the nexus between sustainability reporting and firms' performance. The reason for the inconclusive report may be as a result of a small sample size, inconsistency in SR index (dichotomous or polychromous index), absence of validity and reliability test on index employed, and region studied. This therefore, provides the need for further empirical studies to verify the above reasons.

\section{Empirical review}

Table 1. The Nexus Between Sustainability Reporting and Firm Performance

\begin{tabular}{|c|c|c|c|c|}
\hline$S / n$ & $\begin{array}{l}\text { Authors } \\
\text { (Country) }\end{array}$ & Title of Work & Measures employed & Findings \\
\hline 3 & $\begin{array}{l}\text { Emeka-Nwokeji } \\
\text { and Osisioma (2019) / } \\
\text { (Nigeria) }\end{array}$ & $\begin{array}{l}\text { The impact of susta- } \\
\text { inability disclosures on } \\
\text { market value of non- } \\
\text {-financial quoted firms } \\
\text { in Nigeria. }\end{array}$ & $\begin{array}{l}\text { Sustainability Accoun- } \\
\text { ting Standard Board's } \\
\text { (SASB) Index; via content } \\
\text { analysis and market } \\
\text { value was measured by } \\
\text { Tobin's Q. }\end{array}$ & $\begin{array}{l}\text { Sustainability disclo- } \\
\text { sures had significant } \\
\text { positive effects on firm } \\
\text { value. }\end{array}$ \\
\hline 4 & $\begin{array}{l}\text { Carp, Păvăloaia, } \\
\text { Afrăsinei, and Georgescu } \\
\text { (2019)/ (Romania) }\end{array}$ & $\begin{array}{l}\text { Impact of sustainability } \\
\text { reporting on firms' } \\
\text { growth in Romania } \\
\text { Capital Market. }\end{array}$ & $\begin{array}{l}\text { Both the Global Repor- } \\
\text { ting Initiative's frame- } \\
\text { work and International } \\
\text { Integrated Reporting } \\
\text { Council's framework } \\
\text { (IIRC) via content analy- } \\
\text { sis while firm's growth } \\
\text { was measured using } \\
\text { price-to-book ratio, } \\
\text { sales growth and cost of } \\
\text { capital. }\end{array}$ & $\begin{array}{l}\text { Low influence of susta- } \\
\text { inable reporting on a } \\
\text { firm's growth indicators. } \\
\text { Furthermore, they found } \\
\text { out that sustainability } \\
\text { reporting using both } \\
\text { frameworks (GRI \& IIRC) } \\
\text { do not impact on firms' } \\
\text { growth. }\end{array}$ \\
\hline 5 & $\begin{array}{l}\text { Johari and Komathy } \\
\text { (2019)/ (Malaysia) }\end{array}$ & $\begin{array}{l}\text { The relationship betwe- } \\
\text { en sustainability repor- } \\
\text { ting and firm performan- } \\
\text { ce among public listed } \\
\text { firms in Malaysia. }\end{array}$ & $\begin{array}{l}\text { Sustainability Reporting } \\
\text { was measured using } \\
\text { weighted disclosure } \\
\text { index (dichotomous } \\
\text { index) based on the GRI } \\
\text { framework via content } \\
\text { analysis, while firm } \\
\text { performance was me- } \\
\text { asured by profitability } \\
\text { ratios (ROA \& ROE), and } \\
\text { equity valuation ratio } \\
\text { (EPS \& DPS). }\end{array}$ & $\begin{array}{l}\text { Sustainability repor- } \\
\text { ting had a positive } \\
\text { relationship with firm } \\
\text { performance when using } \\
\text { ROA and EPS. While on } \\
\text { ROE and DPS, there an } \\
\text { insignificant negative } \\
\text { relationship. }\end{array}$ \\
\hline
\end{tabular}


Table 1. The Nexus...

\begin{tabular}{|c|c|c|c|c|}
\hline$S / n$ & $\begin{array}{l}\text { Authors } \\
\text { (Country) }\end{array}$ & Title of Work & Measures employed & Findings \\
\hline 6 & $\begin{array}{l}\text { Uwuigbeet et al., (2018)/ } \\
\text { (Nigeria) }\end{array}$ & $\begin{array}{l}\text { The bi-directional nexus } \\
\text { between sustainability } \\
\text { reporting and firm } \\
\text { performance in quoted } \\
\text { Deposit Money Banks } \\
\text { (DMB) in Nigeria. }\end{array}$ & $\begin{array}{l}\text { Sustainability Reporting } \\
\text { was measured using } \\
\text { unweigted disclosure } \\
\text { index based on the } \\
\text { Global Reporting Initia- } \\
\text { tive's (GRI) framework } \\
\text { (polychotomies scoring } \\
\text { technique) via content } \\
\text { analysis, while firm } \\
\text { performance was measu- } \\
\text { red by Return on Asset } \\
\text { (ROA), Market Price } \\
\text { (MPS), Book Value per } \\
\text { Share (BVPS), Earning per } \\
\text { Share (EPS) and Revenue } \\
\text { of firms investigated. }\end{array}$ & $\begin{array}{l}\text { A bi-directional nexus } \\
\text { between sustainability } \\
\text { reporting and firm per- } \\
\text { formance. Furthermore, } \\
\text { they found that MPS had } \\
\text { a significant negative } \\
\text { relationship on sustaina- } \\
\text { bility reporting, while } \\
\text { sustainability reporting } \\
\text { had a significant positive } \\
\text { influence on revenue } \\
\text { generation. }\end{array}$ \\
\hline 7 & $\begin{array}{l}\text { Alshehhi, Nobanee and } \\
\text { Khare(2018) }\end{array}$ & $\begin{array}{l}\text { Trend literature review } \\
\text { on the impact of cor- } \\
\text { porate sustainability } \\
\text { on corporate financial } \\
\text { performance. }\end{array}$ & $\begin{array}{l}\text { A total of } 132 \text { papers } \\
\text { from top-tier journals } \\
\text { were shortlisted based } \\
\text { on content analysis from } \\
2002-2017 \text {. }\end{array}$ & $\begin{array}{l}78 \% \text { of publications } \\
\text { report a positive rela- } \\
\text { tionship between corpo- } \\
\text { rate sustainability and } \\
\text { financial performance } \\
\text { (a proxy for firm per- } \\
\text { formance). Also, mixed } \\
\text { findings on the nexus } \\
\text { exist. }\end{array}$ \\
\hline 8 & $\begin{array}{l}\text { Asuquo, Dada, and } \\
\text { Onyeogaziri (2018)/ } \\
\text { (Nigeria) }\end{array}$ & $\begin{array}{l}\text { The effect of sustainabi- } \\
\text { lity reporting on cor- } \\
\text { porate performance of } \\
\text { selected quoted brewe- } \\
\text { ry firms in Nigeria. }\end{array}$ & $\begin{array}{l}\text { On GRI framework via } \\
\text { content analysis, while } \\
\text { corporate performance } \\
\text { was measured by Return } \\
\text { on Asset (ROA). }\end{array}$ & $\begin{array}{l}\text { The linear regression } \\
\text { result revealed that } \\
\text { Economic Performance } \\
\text { disclosure (ECN), Envi- } \\
\text { ronmental Performance } \\
\text { disclosure (ENV) and } \\
\text { Social Performance } \\
\text { disclosure (SOC) have } \\
\text { no significant effect on } \\
\text { corporate performance } \\
\text { of brewery firms quoted } \\
\text { firms in Nigeria. }\end{array}$ \\
\hline 9 & $\begin{array}{l}\text { Lasker (2018) (Japan, } \\
\text { South Korea, Indonesia, } \\
\text { and India) }\end{array}$ & $\begin{array}{l}\text { Impact of corporate } \\
\text { sustainability reporting } \\
\text { on firm Performance } \\
\text { in Asia. }\end{array}$ & $\begin{array}{l}\text { GRI framework via } \\
\text { content analysis, while } \\
\text { firm performance was } \\
\text { measured by market to } \\
\text { book ratio (MBR) (a mar- } \\
\text { ket based measure). }\end{array}$ & $\begin{array}{l}\text { Significant positive } \\
\text { association between } \\
\text { sustainability reporting } \\
\text { and firm performance. }\end{array}$ \\
\hline 10 & $\begin{array}{l}\text { Nnamani, Onyekwelu, } \\
\text { and Ugwu (2017) } \\
\text { (Nigeria) }\end{array}$ & $\begin{array}{l}\text { Effect of sustainability } \\
\text { accounting on the } \\
\text { financial performance } \\
\text { of listed manufacturing } \\
\text { firms in Nigeria. }\end{array}$ & $\begin{array}{l}\text { Ratio of total personnel } \\
\text { cost to turnover (social } \\
\text { sustainability) and a } \\
\text { ratio of total equity to } \\
\text { total asset (economic } \\
\text { sustainability), while } \\
\text { financial performance } \\
\text { was measured by ROA. }\end{array}$ & $\begin{array}{l}\text { Sustainability has no si- } \\
\text { gnificant relationship on } \\
\text { financial performance } \\
\text { of firms, as both dimen- } \\
\text { sions were not statisti- } \\
\text { cally significant. }\end{array}$ \\
\hline
\end{tabular}


Table 1. The Nexus...

\begin{tabular}{|c|l|l|l|l|}
\hline \hline S/n & \multicolumn{1}{|c|}{$\begin{array}{c}\text { Authors } \\
\text { (Country) }\end{array}$} & \multicolumn{1}{|c|}{ Title of Work } & Measures employed & \multicolumn{1}{|c|}{ Findings } \\
\hline \hline 11 & $\begin{array}{l}\text { Kwaghfan (2015)/ } \\
\text { (Nigeria) }\end{array}$ & $\begin{array}{l}\text { Impact of sustainability } \\
\text { reporting on corporate } \\
\text { performance of selected } \\
\text { quoted companies in } \\
\text { Nigeria. }\end{array}$ & $\begin{array}{l}\text { Sustainability reporting } \\
\text { was measured based } \\
\text { on GRI disclosure index } \\
\text { (polychotomous index) } \\
\text { via content analysis and } \\
\text { corporate performance } \\
\text { was measured using } \\
\text { ROA, ROE, Net profit } \\
\text { margin and earnings per } \\
\text { share. }\end{array}$ & $\begin{array}{l}\text { Sustainability reporting } \\
\text { companies in Nigeria. }\end{array}$ \\
\hline 12 & Ngatia (2014)/ (Kenya) & $\begin{array}{l}\text { Impact sustainability } \\
\text { reporting on financial } \\
\text { performance of selected } \\
\text { companies listed at } \\
\text { the Nairobi securities } \\
\text { exchange in Kenya. }\end{array}$ & $\begin{array}{l}\text { A sample size was one } \\
\text { hundred and ninety- } \\
\text {-seven (197) respon- } \\
\text { dents were utilized. } \\
\text { The primary research } \\
\text { data was collected } \\
\text { from the management } \\
\text { staff working in listed } \\
\text { companies in Kenya via } \\
\text { questionnaire. }\end{array}$ & $\begin{array}{l}\text { The result revealed that } \\
\text { sustainability reporting } \\
\text { positively and signifi- } \\
\text { cantly affects financial } \\
\text { performance. }\end{array}$ \\
\hline \hline
\end{tabular}

S o u r c e : author's compilation, 2019.

\section{FINDINGS IN LITERATURE, CONCLUSION AND RECOMMENDATIONS}

The study reviewed literature on the impact of SR on firms' performance in developing climes. The unique motivation behind the study was rooted on the inconclusive findings on the nexus. The study relied on a systematic review of articles and found out that more studies have carried in developing countries than developed countries from the period of 2014 to 2019. Most of the studies done in developing countries used the GRI framework as index for sustainability reporting and return on assets was the major proxy for firm performance.

We observed that environmental and social disclosures were low among firms in developing climes. Specifically, in the Nigeria, the rate of sustainability disclosure is low. This implies that developing nations (Nigeria inclusive) would not be achieving sustainable development goals before the year 2030 as envisaged by the UN. This is because of the voluntary nature of the report. However, if the report on sustainability issue is made mandatory, then it can be said that the nation is on the path of sustainable development.

Empirically literature revealed that SR positively affects firms' performance. However, there still exist inconclusive findings in literature, this could 
be as result of sample size and sector studies. This could be as result of sectors investigated and the sample size employed. We concluded that SR affected firms' performance positively. In the light of the above, it is recommended that further studies should be carried out on the impact of SR on firms' performance based on the methodological improvement suggested- increasing the sample size of entities investigated to cover all sectors of the economy, and for longer periods.

\section{REFERENCES}

Adam, E.E. (1994). Alternative quality improvement practices and organization performance. Journal of Operations Management, 12(1), 27-44. https://dx.doi. org/10.1016/0272-6963(94)90004-3.

Adams, M., Thornton, B., \& Sepehri, M. (2012). The impact of the pursuit of sustainability on the financial performance of the firm. Journal of Sustainability and Green Business, 1(1), 24-32.

Aggarwal, P. (2013). Impact of sustainability performance of company on its financial performance. A study of listed Indian companies. Global Journal of Management and Business Research Finance, 13(11), 61-69.

Aifuwa, H.O., Saidu, M., Enehizena, O.C., \& Osazevbaru, A. (2019). Accounting information and lending decision: does sustainability disclosure matter? Copernican Journal of Finance and Accounting, 8(4), 61-89. http://dx.doi.org/10.12775/CJFA.2019.018.

Alshehhi, A., Nobanee, H., \& Khare, N. (2018). The Impact of sustainability practices on corporate financial performance: Literature trends and future research potential. Sustainability, 10(494), 1-25. https://dx.doi.org/10.3390/su10020494.

Al-Gamrh, B., \& Al-Dharnari, R.A. (2016). Firm characteristic and corporate social responsibility. International Business Management, 10(8), 4283-4291.

Amacha, E.B., \& Dastance, O. (2017). Sustainability practices as determinants of financial performance: A case of Malaysian corporations. Journal of Asian Finance, Economics and Business, 4(2), 55-68. https://dx.doi.org/10.13106/jafeb.2017.vol4. no2.55.

Asaolu, T.O., Agboola, A.A., Ayoola, T.J., \& Salawu, M.K. (2011). Sustainability reporting in the Nigerian oil and gas sector. Environmental Management Conference Proceedings. Federal University of Agriculture, Abeokuta, Nigeria.

Asuquo, A.I., Dada, E.T., \& Onyeogaziri, U.R. (2018). The effect of sustainability reporting on corporate performance of selected quoted brewery firms in Nigeria. International Journal of Business and Law Research, 6(3), 1-10.

Ayoola, T.J., \& Olasanmi, O.O. (2013). Business case for integrated reporting in Nigeria oil and gas sector. Issues in Social and Environmental Accounting, 7(1), 30-54. https:// dx.doi.org/10.22164/isea.v7i1.74. 
Balabanis, G., Philips, H., \& Lyall, J. (1998). Corporate social responsibility \& economic performance in the top of British companies: Are they linked? European Business Review, 98, 25-44.

Bayoud, N.S., Kavanagh, M., \& Slaughter, G. (2012). Corporate Social Responsibility Disclosure and Corporate Reputation in Developing Countries: The case of Libya. Journal of Business and Policy Research, 7(1), 131-60.

Bebbington, J., \& Unerman, J. (2017). Achieving the United Nations sustainable development goals: an enabling role for academic research. Accounting, Auditing and Accountability Journal, Preprint, 1-24.

Bebbington, J., \& Larrinaga, C. (2014). Accounting and sustainable development: an exploration. Accounting, Organization and Society, 39(6), 395-413. https://dx.doi. org/10.1016/j.aos.2014.01.003.

Beredugo, S.B., \& Mefor, I.K. (2016). The impact of environmental accounting and reporting on sustainable development in Nigeria. Research Journal of Finance and Accounting, 3(7), 55-63.

Bowrin, A.R. (2013). Corporate social and environmental reporting in the Caribbean. Social Responsibility Journal, 9(2), 259-280. https://dx.doi.org/10.1108/SRJ082011-0074.

Brundtland, G.H. (1987). Our Common Future. United Nations World Commission on Environment and Development (Brundtland Commission). Oxford: Oxford University Press.

Burhan, A.H., \& Rahmanti, W. (2012). The impact of sustainability reporting on company performance. Journal of Economics, Business, and Accountancy Ventura, 15(2), 257-272. https://dx.doi.org/10.14414/jebav.v15i2.79.

Carp, M., Păvăloaia, L., Afrăsinei, M., \& Georgescu, J.E. (2019). Is sustainability reporting a business strategy for firm's growth? Empirical study on the Romanian capital market. Sustainability, 11(658), 1-21. https://dx.doi.org/10.3390/su11030658.

Carroll, A. (1999). Corporate social responsibility. Business and Society, 38(3), 268-95. https://dx.doi.org/10.1177/000765039903800303.

Cherrington, D.J. (1989). Organizational behavior: The management of individual and organizational performance. London: Allyn \& Bacon.

Ching, H.Y., Gerab, F., \& Toste, T.H (2017). The quality of sustainability reports and corporate financial performance: Evidence from Brazilian listed companies. SAGE Open, April-June 2017, 1-9. https://dx.doi.org/10.1177/2158244017712027.

Dhaliwal, D.S., Li, O.Z., Tsang, A., \& Yang, Y.G. (2011). Voluntary non-financial disclosure and the cost of equity capital: The initiation of corporate social responsibility reporting. The Accounting Review, 86(1), 59-100. https://dx.doi.org/10.2308/ accr.00000005.

Diantimala, Y. (2018). The mediating effect of sustainability disclosure on the relationship between financial performance and firm value. Journal of Accounting, Finance and Auditing Studies, 4(2), 32-48.

Elkington, J. (2004). Enter the triple bottom line. In A. Henriques, J. Richardson (Eds.). The Triple Bottom Line: Does it All Add Up? Assessing the Sustainability of Business and CSR. London: Earthscan. 
Ekweme, C.M., Egbunike, C.F., \& Onyali, C.I. (2016). Benefits of triple bottom line disclosures on corporate performance: An exploratory study of corporate stakeholders. Journal of Management and Sustainability, 3(2), 79-91. https://dx.doi.org/10.5539/ jms.v3n2p79.

Emeka-Nwokeji, N.A., \& Osisioma, B.C. (2019). Sustainability reporting and market value of firms in emerging economy: Evidence front Nigeria. European Journal of Accounting, Auditing and Finance Research, 7(3), 1-19.

Georgopoulos, B.S., \& Tannenbaum, A.S. (1957). A study of organizational effectiveness. American Sociological Review, 22, 534-540. https://dx.doi.org/10.2307/2089477.

Global Reporting Initiative (2019). What is Sustainability reporting, https://www.gri. org (accessed: 19.12.2019).

Global Reporting Initiative (2015). Reporting Principles and Standard Disclosure, https://www.globalreporting.org/standards/g4/Pages/interpretations.pdf (accessed: 19.12.2019).

Gulzar, M.A., Cherian, J., Sial, M.S., Badulescu, A., Thu, P.A., Badulescu, D., \& Khuong, N.V. (2018). Does corporate social responsibility influence corporate tax avoidance of Chinese listed companies? Sustainability, 10(12), 1-12. https://dx.doi. org/10.3390/su10124549.

Gunarsih, T., \& Ismawati, Y. (2018). Sustainability reports and firm performance: study in mining and metal \& food processing industry in Indonesia stock exchange. Journal of Governance and Integrity, 2(1), 9-26.

Hahn, T., Preuss, L., Pinkse, J., \& Figge, F. (2014). Cognitive frames in corporate sustainability: managerial sensemaking with paradoxical and business case frames. Academy of Management Review, 39(4), 463-487. https://dx.doi.org/10.5465/ amr.2012.0341.

Haladu, A., \& Salim, B. (2017). Sustainability reporting by firms in the Nigerian economy: Social versus economic disclosure. Journal of Accounting and Finance in Emerging Economics, 3(2), 87-111. https://dx.doi.org/10.26710/jafee.v3i2.96.

Harrison, J.S., \& Freeman, R.E. (1999). Stakeholders, social responsibility, and performance: Empirical evidence and theoretical perspectives. The Academy of Management Journal, 42(5), 479-485. https://dx.doi.org/10.2307/256971.

Hashmi, M.A., Damanhouri, A., \& Rana, D. (2015). Evaluation of sustainability practices in the United States and large corporations. Journal of Business Ethics, 127(3), 673-681. https://dx.doi.org/10.1007/s10551-014-2056-4.

Hopkins, M. (2005). Measurement of corporate social responsibility. International Journal of Management and Decision Making, 6(3), 213-231. https://dx.doi.org/10.1504/ IJMDM.2005.006549.

Isa, M.A. (2014). Sustainability reporting a mong Nigeria food and beverage firms. International Journal of Agriculture and Economic Development, 2(1), 1-9.

Isaiah, O.M., Selvam, M., Vinayagamoorthi, V., Kasilingam, L., \& Mariappan, R. (2015). Efficiency measurement of Kenyan commercial banks. Mediterranean Journal of Social Sciences, 6(4), 621-631. http://dx.doi.org/10.5901/mjss.2015.v6n4s2p621. 
Ismail, K., \& Ibrahim, A.H. (2010). Social and environmental disclosure in the annual Reports of Jordanian Companies. Issues in Social \& Environmental Accounting, 2, 198-210. https://dx.doi.org/10.22164/isea.v2i2.32.

Johari, J., \& Komathy (2019). Sustainability reporting and firm performance: Evidence in Malaysia. International Journal of Accounting, Finance and Business, 4(17), 1-7.

Jones, M. (2014). Accounting for biodiversity. London: Rutledge.

Joseph, U.B. (2016). Effect of sustainability reporting on firm's performance: A review of literature. The International Journal of Business \& Management, 4(7), 203-208.

Kathyayini, K., Tilt, C.A., \& Lester, L.H. (2012). Corporate governance and environmental reporting: an Australian study. Corporate Governance, 12(2), 143-163. https:// dx.doi.org/10.1108/14720701211214052.

Katz, D., \& Kahn, R.L. (1978). The social psychology of organizations. New York: Wiley.

Kim, R. (2016). The nexus between international law and the sustainable development goals. Review of European Community \& International Environmental Management, 25(1), 15-26. https://dx.doi.org/10.1111/reel.12148.

KPMG (2017). The KPMG Survey of Corporate Responsibility Reporting 2017, https:// home.kpmg/content/dam/kpmg/campaigns/csr/pdf/CSR_Reporting_2017.pdf (accessed: 19.12.2019).

KPMG (2011). KPMG International survey of corporate responsibility reporting, https:// www.kpmg.com/AU/en/IssuesAndInsights/ArticlesPublications/Documents/kpmginternational-survey-corporate-responsibility-reporting-2011.pdf (accessed: 19.12. 2019).

Kusuma, P.A., \& Koesrindartoto, D.P. (2014). Sustainability practices and financial performance: An empirical evidence from Indonesia. International Conference on Trends in Economics, Humanities and Management (ICTEHM'14), Thailand. https://dx.doi. org/10.15242/ICEHM.ED0814010.

Kwaghfan, A. (2015). Impact of sustainability reporting on corporate performance of selected quoted companies in Nigeria. Unpublished $\mathrm{PhD}$ thesis. Enugu, Nigeria: University of Nigeria.

Laskar, N. (2018). Impact of corporate sustainability reporting on firm performance: An Empirical examination. Asia Journal of Asia Business Studies, 12(4), 1-38. https:// dx.doi.org/10.1108/JABS-11-2016-0157.

Lebans, M., \& Euske, K. (2006). A conceptual and operational delineation of performance. Business Performance Measurement. London: Cambridge University Press.

Lupton, T. (1977). Organizational Behavior and Performance. London: The Macmillan Press.

Miller, S.J., Wardrop, D.H., Mahaney, W.M., \& Brooks, R.P. (2006). A plant-based index of biological integrity (IBI) for headwaters wetlands in central Pennsylvania. Ecological Indicators, 6(2), 290-312. https://dx.doi.org/10.1016/j.ecolind.2005.03.011.

Muñoz, E., Zhao, L., \& Yang, D.C. (2017). Issues in sustainability accounting reporting. Accounting and Finance Research, 6(3), 64-71. https://dx.doi.org/10.5430/afr. v6n3p64. 
Ngatia, C.N. (2014). Exploring sustainability reporting for financial performance of selected companies listed at the Nairobi Securities Exchange in Kenya. International Academic Journal of Economics and Finance, 1(4), 32-48.

Nnamani, J.N, Onyekwelu, U.L., \& Ugwu, O.K. (2017). Effect of sustainability accounting on the financial performance of firms in the Nigerian brewery sector. European Journal of Business and Innovation Research, 5(1), 1-15.

Nwobu, 0. (2015). The relationship between corporate sustainability reporting and profitability and shareholders fund in Nigerian banks. Journal of Accounting and Management, 5(3), 1-20.

Ofoegbu, G.N., Odoemelam, N., \& Okafor, R.G. (2018). Corporate board characteristics and environmental disclosure quantity: Evidence from South Africa (integrated reporting) and Nigeria (traditional reporting). Cogent Business \& Management, 5, 3-27. https://dx.doi.org/10.1080/23311975.2018.1551510.

Onyekwelu, U.L., \& Ekwe, M.C. (2014). Does corporate social responsibility predicate good financial performance. ESUT Journal of Management Sciences, 8(1)1-10.

Onyekwelu, U.L., \& Ugwuanyi, B.U. (2014). Corporate social accounting and the enhancement of information disclosures among firms: A study of selected firms in $\mathrm{Ni}-$ geria. Journal of Economics and Sustainable Development, 5(6), 35-44.

Owolabi, F., Taleatu, A., Adetula, D., \& Uwuigbe, U. (2016). Assessment of sustainability reporting in Nigerian industrial goods sector. $3^{\text {rd }}$ International Conference on African Development Issues, Covenant University, Ota, Nigeria, 383-386.

Popa, A., Blidisel, R., \& Bogdan, V. (2009). Transparency and disclosure between theory and practice, A case study of Romania. Proceedings of Fikusz 09 Symposium for Young researchers. https://www.kgk.bmf.hu/fikusz (accessed: 19.12.2019).

Robbins, S.P. (1987). Organizational Theory: Structure, Design, and Application. San Diego: Prentice-Hall.

Sadia, M., Tariq, A., \& Saba, S. (2015). The effect of corporate governance elements on corporate social responsibility (CSR) disclosure in Pakistan. Int. J. Financial Stud, 3(4), 530556. https://dx.doi.org/10.3390/ijfs3040530.

Saha, A.K., \& Akter, S. (2013). Relationship between environmental reporting in corporate annual reports \& corporate profitability in Bangladesh. Global Conference on Business \& Finance Proceedings, 8(1), 75-86.

Santos, J.B., \& Brito, L.A.L. (2012). Toward a Subjective Measurement Model for Firm Performance. Brazilian Administration Review, 9, 95-117. https://dx.doi.org/10.1590/ S1807-76922012000500007.

Siew, R.Y.J., Balabat, M.C.A., Carmichael, D.G. (2013). The relationship between sustainability practices and financial performance of construction companies. Smart and Sustainable Built Environment, 2(1), 6-27.

Selvam, M., Gayathri, J., Vasanth, V., Lingaraja, K., \& Marxiaoli, S. (2016). Determinants of firm performance: A subjective model. International Journal of Social Science Studies, 4(7), 90-100. https://dx.doi.org/10.11114/ijsss.v4i7.1662.

Selvam, M. (2016). Service efficiency of pallavan transport corporation limited in Madras. India: Lambert Academic Publishing. 
Shamil, M., Shaikh, J.M., Ho, P., \& Krishnan, A.A. (2014). The influence of board characteristics on sustainability reporting Empirical evidence from Sri Lankan firms. Asian Review of Accounting, 22(2), 78-97. https://dx.doi.org/10.1108/ARA-09-20130060.

Statman, M.D., \& Glushkov, D. (2019). The wages of social responsibility. Financial Analysts Journal, 65(4), 33-46. https://dx.doi.org/10.2469/faj.v65.n4.5.

Taouab, O., \& Issor, Z. (2019). Firm performance: Definition and measurement models. European Scientific Journal, 15(1), 93-106. https://dx.doi.org/10.19044/esj.2019. v15n1p93.

United Nations (2016). The sustainable development goals report. United Nations, New York.

Utami, W. (2015). Financial performance and the quality of sustainability disclosure based on Global Reporting Initiative: Value relevance study in Indonesia stock exchange. Mediterranean Journal of Social Sciences, 6(5), 243-248 https://dx.doi. org/10.5901/mjss.2015.v6n5s5p243.

Uwuigbe, U., Obarakpo, T., Uwuigbe, O.R., Ozordi, E., Asiriuwa, O., Eyitomi, G.A., \& Taiwo, O.S. (2018). Sustainability reporting and firm performance: A bi-directional approach. Academy of Strategic Management Journal, 17(3), 1-16.

Venanzi, D. (2012). Social ratings and financial performance: An instrumental approach. SSRN Electronic Journal. https://dx.doi.org/10.2139/ssrn.2188859.

Willis, A., Campagnoni, P., \& Gee, W. (2015). An evolving corporate reporting landscape. Toronto, Ontario: Chartered Professional Accountants of Canada.

Wokeck, L. (2019). Corporate sustainability reporting in least developed countries: Challenges and opportunities for action. Occasional Policy Paper on Least Developed Countries, 6, 1-31.

Yuchtman, E., \& Seashore, S. (1967). Factorial analysis of organizational performance.Administrative Science Quarterly, 12(3), 377-395. https://dx.doi.org/10.2307/2391311. 